\title{
Prioritizing conservation areas for coastal plant diversity under increasing urbanization
}

\author{
Aggeliki Doxa ${ }^{\mathrm{a},{ }^{*}}$, Cécile Hélène Albert ${ }^{\mathrm{a}}$, Agathe Leriche ${ }^{\mathrm{b}}$, Arne Saatkamp ${ }^{\mathrm{a}}$ \\ a Institut Méditerranéen de Biodiversité et d'Ecologie (IMBE), Aix Marseille Université, Avignon Université, CNRS, IRD, Faculté de St-Jérôme, 13397 Marseille \\ cedex 20, France \\ ${ }^{\mathrm{b}}$ Institut Méditerranéen de Biodiversité et d'Ecologie (IMBE), Aix Marseille Université, Avignon Université, CNRS, IRD, Europôle méditerranéen de l'Arbois - \\ BP 80, 13545 Aix-en-Provence cedex 04, France
}

\begin{abstract}
A B S T R A C T
Coastal urban expansion will continue to drive further biodiversity losses, if conservation targets for coastal ecosystems are not defined and met. Prioritizing areas for future protected area networks is thus an urgent task in such urbanization-threatened ecosystems. Our aim is to quantify past and future losses of coastal vegetation priority areas due to urbanization and assess the effectiveness of the existing protected area network for conservation.

We conduct a prioritization analysis, based on 82 coastal plants, including common and IUCN red list species, in a highly-urbanized but biotically diverse region, in South-Eastern France. We evaluate the role of protected areas, by taking into account both strict and multi-use areas. We assess the impact of past and future urbanization on high priority areas, by combining prioritization analyses and urbanization models.

We show that half of the highly diverse areas have already been lost due to urbanization. Remaining top priority areas are also among the most exposed to future urban expansion. The effectiveness of the existing protected area (PA) network is only partial. While strict PAs coincide well with top priority areas, they only represent less than one third of priority areas. The effectiveness of multi-use PAs, such as the Natura 2000 network, also remains limited.

Our approach highlights the impact of urbanization on plant conservation targets. By modelling urbanization, we manage to identify those areas where protection could be more efficient to limit further losses. We suggest to use our approach in the future to expand the PA network in order to achieve the 2020 Aichi biodiversity targets.
\end{abstract}

\section{Introduction}

Urbanization is one of the main factors of long-lasting land transformation and a major threat to biodiversity worldwide (Grimm et al., 2008; McKinney, 2002; Seto et al., 2011). Coastal areas are particularly affected by both increasing urban population and mass tourism that lead to the rapid development of urbanized areas and consequently to losses of natural habitats (Airoldi and Beck, 2007; Bulleri and Chapman, 2010). Connecting land and sea, coastal habitats often stand out by a unique plant diversity and

\footnotetext{
* Corresponding author.

E-mail address: aggeliki.doxa@imbe.fr (A. Doxa).
}

high specialisation within strong ecological gradients at small spatial scales (Médail and Quézel, 1997). Many coastal plants are adapted to stressful levels of salinity, drought and temperature (Baastrup-Spohr et al., 2015; Malcolm and Zedler, 1995) and are thus highly vulnerable to habitat decrease (Stefanaki et al., 2015). The conflict between human pressures and conservation of irreplaceable, vulnerable biodiversity makes prioritizing conservation actions within coastal zones particularly urgent.

The Mediterranean basin is a typical example, even though it covers only $2 \%$ of the Earth's land surface, it holds over $20 \%$ of the known vascular plant species. It harbours particularly high proportions (>50\%) of endemic species (Greuter, 1994; Médail and Quézel, 1997). Therefore, Mediterranean coasts are recognized for their important diversity of habitats and species (Cox and 
Underwood, 2011). In parallel, the long human history in the Mediterranean has led to densely populated cities within narrow coastal fringes (UNPD, 2012). Nevertheless, we still know little of what has already been lost (but see Brown and McLachlan, 2006 for dune ecosystems) and whether current protected areas (PAs) are effective for conservation of coastal biodiversity against urbanization.

Adequately protecting the coastal diversity with appropriate conservation measures requires coordinating conservation efforts for the designation of new reserves (Cox and Underwood, 2011) and accounting for species with various rarity and vulnerability levels (Gauthier et al., 2013, 2010). The development of systematic conservation planning (Margules and Pressey, 2000) permits the identification of irreplaceable areas with regard to biodiversity and the optimization of conservation efforts so as to increase complementarity among reserves (Brooks et al., 2006; Cabeza and Moilanen, 2001). Systematic conservation planning also enables to take vulnerability into account and thus to react faster to potential human pressures (Pressey et al., 2007, 2004). To anticipate future losses of priority areas due to urbanization and to meet conservation targets, reserve planning should combine information from species distribution, prioritization and land-use modelling (Montesino Pouzols et al., 2014).

Plant species vary in habitat specificity, which interacts with threats due to human activities. For example, in dune habitats plant biodiversity has already largely been lost and most of the remaining species, though widespread, are threatened by extinction (Lavergne et al., 2004; Lhotte et al., 2014). Contrastingly, endemic species from rocky outcrops are rare and narrow-ranged, but their habitat is little amenable to deterioration, including to urbanization (Lavergne et al., 2005). These examples highlight why it is important to separate regressing and rare species. Therefore, we advocate the use of IUCN criteria documented in red list classifications to achieve this distinction (Noble et al., 2015). While these contrasted cases are not clearly separated in global assessments such as IUCN red lists, new criteria for prioritization have been proposed (Bacchetta et al., 2011; Gauthier et al., 2010; Schatz et al., 2014). Given the contrasting significance of rarity and decline for conservation, we decided to specifically focus on rare and declining species separately.

Here we propose 1) to quantify past, present and future losses of coastal habitats due to urbanization, based on the irreplaceability of their flora, 2) to assess the effectiveness of existing protected areas (PAs) for conservation of coastal plant diversity and to define the importance of strict compared to multi-use PAs (Brooks et al., 2006; Leroux et al., 2010; McDonald and Boucher, 2011), and 3) to identify non-protected high priority areas, that would optimally complement the existing network. We worked on the coast of the Provence-Alpes-Côtes d'Azur region in France, a densely populated and highly visited tourist destination. One quarter of the areas that were urbanized during the period 1990-2012 lie within the first $15 \mathrm{~km}$ from the coast, in Mediterranean habitats of an exceptionally rich plant diversity, including unique coastal dune and rocky habitats and two thirds of the plant species found in France (Médail and Verlaque, 1997).

We conducted several scenarios of conservation prioritization analyses, based on species distribution models. First, we prioritized areas based on all coastal plants, and then did a separate analysis for plants with conservation status according to IUCN, by separating further rare and declining plants. Secondly, we combined conservation priorities with a simple urbanization model to assess what has already been lost due to urbanization and what could be lost in the near future. We propose to extend protected areas to $17 \%$ of the coastal area in order to meet the 2020 Aichi biodiversity targets and to optimally prevent future plant diversity losses. Our results have interesting implications for conservation in the Mediterranean region and our approach is applicable to any type of ecosystem.

\section{Material and methods}

\subsection{Study region and plant data}

The analysis was conducted on the coastal zone of the ProvenceAlpes-Côte d'Azur (PACA) region in France. We focussed on a 10-km band from sea, where urbanization mostly impacts coastal vegetation and challenges existing conservation plans. We accounted for all protected areas (PAs) situated within this coastal zone (Fig. 1) and separated them into two categories: 'strict' and 'multi-use' PAs, using the IUCN protected area categories (McDonald and Boucher, 2011). We considered protected areas as 'strict', when their conservation status effectively restricts human activities, including National Parks, National Nature Reserves, areas managed by the French Coastal Conservation Agency (Conservatoire du Littoral) and

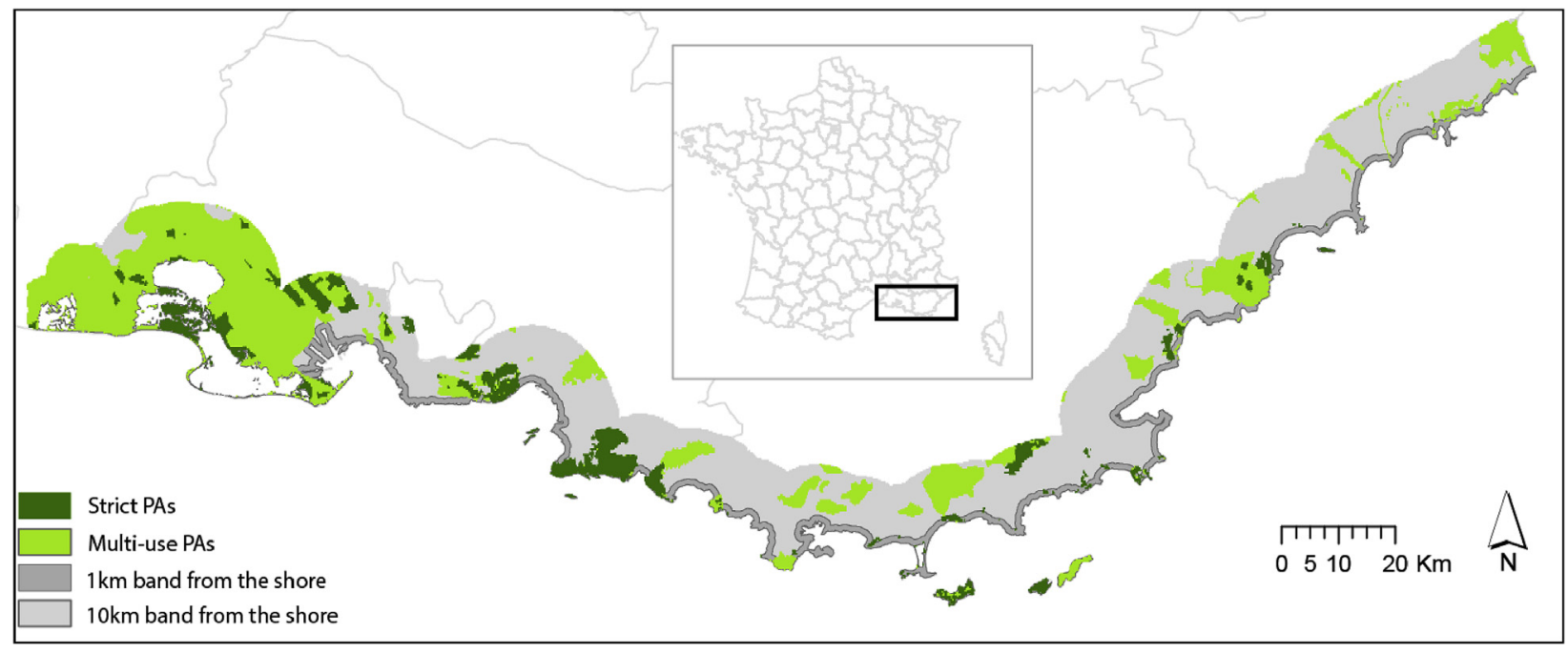

Fig. 1. Study region and existing strict and multi-use protected areas. 
Biological Reserves. In the 'multi-use' category, we considered areas where human activities can only be managed, including Regional Natural Parks, Regional Nature Reserves, Biotope Protection and Natura 2000 areas.

We retrieved plant occurrence data from SILENE (http://flore. silene.eu/), a database combining all known plant occurrences for South Eastern France. Species of conservation interest are well documented in SILENE (Noble et al., 2015), making it particularly useful for the present study. To focus on coastal plants, we considered only indigenous species with at least 50 occurrences within the $10-\mathrm{km}$ zone and $75 \%$ of their occurrences within a $1-\mathrm{km}$ distance from the coast. We further restricted this list by eliminating species that can also be found in hinterland habitats, based on national plant distributions maps (http://www.tela-botanica. org/). This resulted in 82 species, of which 34 are of specific conservation interest - particularly rare or declining (Vela et al., 2001) according to the regional IUCN red list (Noble et al., 2015; see Supplementary Appendix 1 for coastal species list). We further used the IUCN red list criteria to separate 'rare' $(\mathrm{N}=15)$ and 'declining' $(\mathrm{N}=19)$ species within the region (see Appendix 1 for species categorization).

\subsection{Species distribution modelling}

Coastal habitats have fine-scale environmental gradients with narrow species distribution areas and thus narrow conservation units. However, plant occurrence data are typically at coarse resolution (Araujo et al., 2005). To take advantage of environmental data available at high resolution, and information in accurately located point data, we used species distribution models (SDM) as a basis for systematic conservation planning for coastal habitats. We projected the potential distribution of each of the 82 coastal species individually using SDM with the BIOMOD2 library in $\mathrm{R}$ (Thuiller et al., 2009). We considered a $250 \times 250 \mathrm{~m}$ resolution using six environmental variables expected to be important for coastal plant species (Fenu et al., 2013; Forey et al., 2008; Ruocco et al., 2014): two uncorrelated $(\mathrm{r}<0.3)$ climate variables available in the WorldClim database (Hijmans et al., 2005) i.e. the minimum temperature of the coldest month (BIO6) and the precipitation of the warmest quarter (BIO18), one soil variable reflecting strong $\mathrm{pH}$ gradient, the annual sun exposure, the ground slope, used as a proxy for water availability, and a variable of maritime influence, used as a proxy for salinity (ex. Seavey et al., 2011; for additional information on variables and their importance for modelling species potential distribution, see Appendix 2).

Within each $250 \mathrm{~m}$ grid cell, all corresponding occurrences were pooled and attributed to its centre. Pseudo-absences were selected by a distance of $2.5 \mathrm{~km}$, consistent with spatial autocorrelation and population sizes for plants in our area (Pouget et al., 2016). We used ten times more pseudo-absences than occurrences and ran repetitions with ten different sets of pseudo-absences (Barbet-Massin et al., 2012). We used three different species distribution model (SDM) approaches, which all performed well and enabled the use of categorical variables (Elith et al., 2006; Thuiller et al., 2003): Generalized Linear Model (GLM), Classification Tree Analysis (CTA), and Random Forests (RF). For each species, SDMs were parameterized on $80 \%$ of occurrences and accuracy was assessed using true skill statistic (TSS) on the remaining $20 \%$, with three repeated random data splits. The high median TSS of split-data $(0.79$ [0-1]) and full models $(0.91[0.2-1])$ indicated a good predictive power (SDM details in Appendix 2). We then used all 30 full models (3 algorithms * 10 pseudo-absences selections) per species for the conservation prioritization analyses. We projected SDMs to the entire study region and converted them then into binary layers based on the maximizing TSS.

\subsection{Urbanization within the coastal zone}

To understand how recent urbanization has affected high conservation value areas for coastal plant species, we accounted for urban cover changes for the period 1990 to 2012. We used the first level categorization of the Corine Land Cover (hereafter CLC) raster database (http://www.statistiques.developpement-durable.gouv. $\mathrm{fr} / \mathrm{clc} /$ carte/metropole) at $250 \times 250 \mathrm{~m}$. We distinguished between 5 land-cover categories, 1: urban surfaces, 2: agricultural areas, 3: forest and semi-natural areas and 4\&5: wetlands and water bodies. We subtracted any recently urbanized area, i.e. that has changed from categories 2 or 3 to category 1 in any of the three CLC change layers (1990-2000, 2000-2006, 2006-2012) from the 2012 baseline as an estimate of urban areas in 1990.

Following the land use change literature (Aspinall, 2004; Hu and Lo, 2007; Li and Yang, 2015), we also ran statistical models in the same framework as used for SDMs. In this way, we generated a map of land cover transition probabilities relating observed urbanization to local environmental variables. We also randomly selected ten sets of 'pseudo-absences', to identify areas that could have but have not yet been urbanized (areas that remain in categories 2 or 3). We then ran a GLM with the BIOMOD2 library to relate occurrences and pseudo-absences to distance to roads, ground slope and distance to the coast which all are often found to be important for the urbanization process, i.e. (Bürgi et al., 2004). Models were calibrated and evaluated as detailed above for SDMs and had good predictive power (mean TSS: 0.58 ). Since models were very similar, we picked one as reference layer for probability to become urban. Given that the coverage of urban areas was 23\% of total area in 1990 and $24 \%$ of total area in 2012, we run three future scenarios with $25,26,30 \%$ urban cover and four past scenarios with $5,10,15,19 \%$, by adding or removing cells with the highest or lowest probabilities to become urban to the 2012 CLC status layer or 1990 CLC map. Based on a simple linear relationship between regional human population and percentage of urban area coverage, $19 \%$ can be used as an estimate for the year 1968 and 25\% for 2034 (INSEE “central scenario"; Léon and Godefroy, 2006).

\subsection{Conservation prioritization analysis}

We identified conservation priorities using the Zonation algorithm (Lehtomäki and Moilanen, 2013; Moilanen et al., 2011b, 2009), which ranks cells using irreplaceability. Irreplaceability evaluates the uniqueness of a cell in terms of species composition compared to other cells, notably considering mismatch and redundancies between species distributions. Cells with the highest irreplaceability should be considered first for conservation actions since their degradation leads to definitive losses (Cabeza and Moilanen, 2001).

We used a post-selection consensus procedure to obtain the final priority ranking, following Meller et al. (2014). We repeated the ranking 100 times with one binary layer of potential species distribution per species randomly selected out of the 30 available projections (see SDM section). The final conservation ranking of the cells corresponded to the mean value of these 100 rankings (Meller et al., 2014). All species were weighted equally and no information on land cost was used.

To address our objectives, we ran six different prioritization analyses. We considered three different sets of species: 1) all coastal species $(n=82), 2)$ rare coastal species $(n=15)$ and 3$)$ declining coastal species $(n=19)$. To account for the effect of past urbanization, we ran the analysis for each of these species sets twice: 1) In a 'hypothetical' scenario, we assumed that the entire region is available as coastal habitat, i.e. this leads to identification of areas that would have been top conservation priorities if no 
urbanization existed within our study region. We then estimated the overlap between the ranked conservation priorities and urban areas in 2012 (see previous section) to identify what was lost from the potential coastal biodiversity due to past urbanization. To obtain the proportion of overlap, we followed Meller et al. (2014) for the whole range of area thresholds i.e. from $1 \%$ to $100 \%$ of the study region ranked in decreasing priority. 2) In an 'ideal' scenario, we reran the prioritization analysis by removing the 2012 urban areas prior to the ranking procedure, which allows only habitat which is actually remaining to be ranked as a top conservation priority. We call this scenario ideal, because all non-urban areas are potentially considered for conservation, and no cost analysis of setting land aside for conservation is considered. Completely excluding areas at the starting point of the prioritization analysis is advised in cases where it is known that the masked sites will not support biodiversity, in our case, urban areas (Moilanen et al., 2014). We then assessed the effectiveness of current protected areas by overlapping the ranked conservation priorities for the range of area thresholds with strict and multi-use protected areas separated.

We used the percentage of protected areas in the entire study region as a reference to assess whether priority areas are under- or over-represented in the protected areas (Doxa et al., 2016; Mouillot et al., 2011). If PAs are effectively located to encompass important areas for the conservation of coastal plant diversity, one might expect that high-ranking sites will be preferentially included within the PAs. If high-ranking sites are under-represented in PAs, i.e. lower than the overall proportion within protected areas, this would indicate low effectiveness of the corresponding PAs. We adopted the same concept for the urbanization analysis, to estimate whether urban areas are over- or under-represented in what would have been high-ranking sites for coastal vegetation.

Although systematically using the whole range of area thresholds for our results, we specifically focused on the top $10 \%$ (representing a surface area of $354 \mathrm{~km}^{2}$ ) of conservation priorities. This threshold is of interest for setting conservation objectives for conservation practitioners as it remains realistic and follows current trends in the literature (Jenkins and Joppa, 2009; Meller et al., 2014). We estimated the specific contribution of each of the eight protected area categories to this specific top 10\% target, by calculating separately the overlap between high priority areas and each protected area category.

In order to predict impacts of future urbanization and to match the 2020 Aichi biodiversity target, we also studied the top $17 \%$ fraction as future conservation priorities. We extended the existing strict PA network by masking urban areas and strict PAs prior to the prioritization analysis. The existing strict PA network covered $8 \%$ of the study region, so we added another $9 \%$ of top-ranking cells that fall outside existing strict PAs. We then ran urbanization scenarios by restricting urbanization to occur outside strict PAs. We finally quantified possible future losses with and without additional conservation effort by estimating the overlap between future urban areas with both top $10 \%$ and top $17 \%$ priority areas.

\section{Results}

\subsection{Effect of current and past urbanization}

The priority conservation areas without removing urban areas based on all coastal species and the two IUCN categories separately are shown in Fig. 2. Declining species priority areas are mainly located in the central and western part of the study region, with some limited but high-ranking areas in the eastern part. For rare species, high priority areas are mainly located in the central part of the region. When considering all 82 coastal plant species, priority areas are identified along the entire coastline, and species distributions were not strongly aggregated in hotspots.

The overlap of the top priority fraction with the actual urban areas varied from $43 \%$ for declining species, to $48 \%$ for all coastal plant species and up to over 52\% for rare species (Fig. 3ii). This overlap further reduced when lower ranking sites were included, to reach a final overlap of $24 \%$, which corresponds to the actual cover of urban areas within the study region. Existing cities are overrepresented in areas that would have been hotspots for coastal plants.

These results were slightly different when using the 1990 CLC urban cover, i.e. $42 \%$ overlap with the declining species priority areas, $47 \%$ overlap with all species priority areas and 51\% overlap with rare species priority areas (Fig. 3i). Only a small fraction of irreplaceable areas for coastal biodiversity has been lost during the last two decades. Overlaps still remained high when considering older periods of urban extension: urban cover modelled for 1968 overlapped at $40 \%$ with priority areas of declining species, at $45 \%$ with priority areas of all species and at $48 \%$ with priority areas of rare species. Overlaps between coastal plant priority and urban areas only sharply decreased for lower (5-15\%) urban cover (Fig. 3i). Most irreplaceable areas for coastal biodiversity thus seem to have been lost before the 1960s. Interestingly, the lowest urban cover scenario of $5 \%$ cover overlapped at $20 \%$ with priority areas, indicating that coastal cities were developed in areas with high plant diversity.

\subsection{Identifying remaining priority areas and defining conservation targets}

By including the top $10 \%$ priority fraction in protected areas, we manage to protect on average $20 \%$ of all species distributions, $25 \%$ of the declining species distributions and $32 \%$ of the rare species distributions (Fig. 4). Increasing the priority targets from $10 \%$ to $20 \%$ of the study region would favour species with a conservation interest, by including on average $48 \%$ of the rare species distributions and $40 \%$ of the declining species distributions, while still protecting $30 \%$ of all coastal species distributions. The cumulative proportion of plant distribution areas included in protected areas increases almost linearly when increasing protected areas for all coastal plant species linked to species distributions low aggregation. Contrastingly, cumulative proportion increases steeper for rare and declining species linked to their stronger aggregation and reaches a plateau around $30-40 \%$ of the area protected.

\subsection{Effectiveness of protected areas for conservation priorities}

We revealed that $42 \%$ of the top priority fraction of all considered plant species are included in PAs, varying from $36 \%$ for rare species to $59 \%$ for declining species (Fig. $5 \mathrm{i}$ ). However, only half of these percentages correspond to strict PAs i.e. 21\% for all species, $20 \%$ for rare species and $28 \%$ for declining species (Fig. $5 \mathrm{ii}$ ). For strict protected areas, the maximum overlap is obtained within the top priority fraction, meaning that all three species groups are overrepresented in strict PAs. This supports the geographical choice of the strict PAs for the conservation of coastal plants, even though the percentages of overlap still remain relatively low, i.e. $70-80 \%$ of the priority areas remain outside strict PAs. Contrastingly, percentages of priority areas for all species are lower in multi-use PAs than in the entire study region, and even lower for rare species. Location of multi-use PAs did not coincide with a conservation target for 

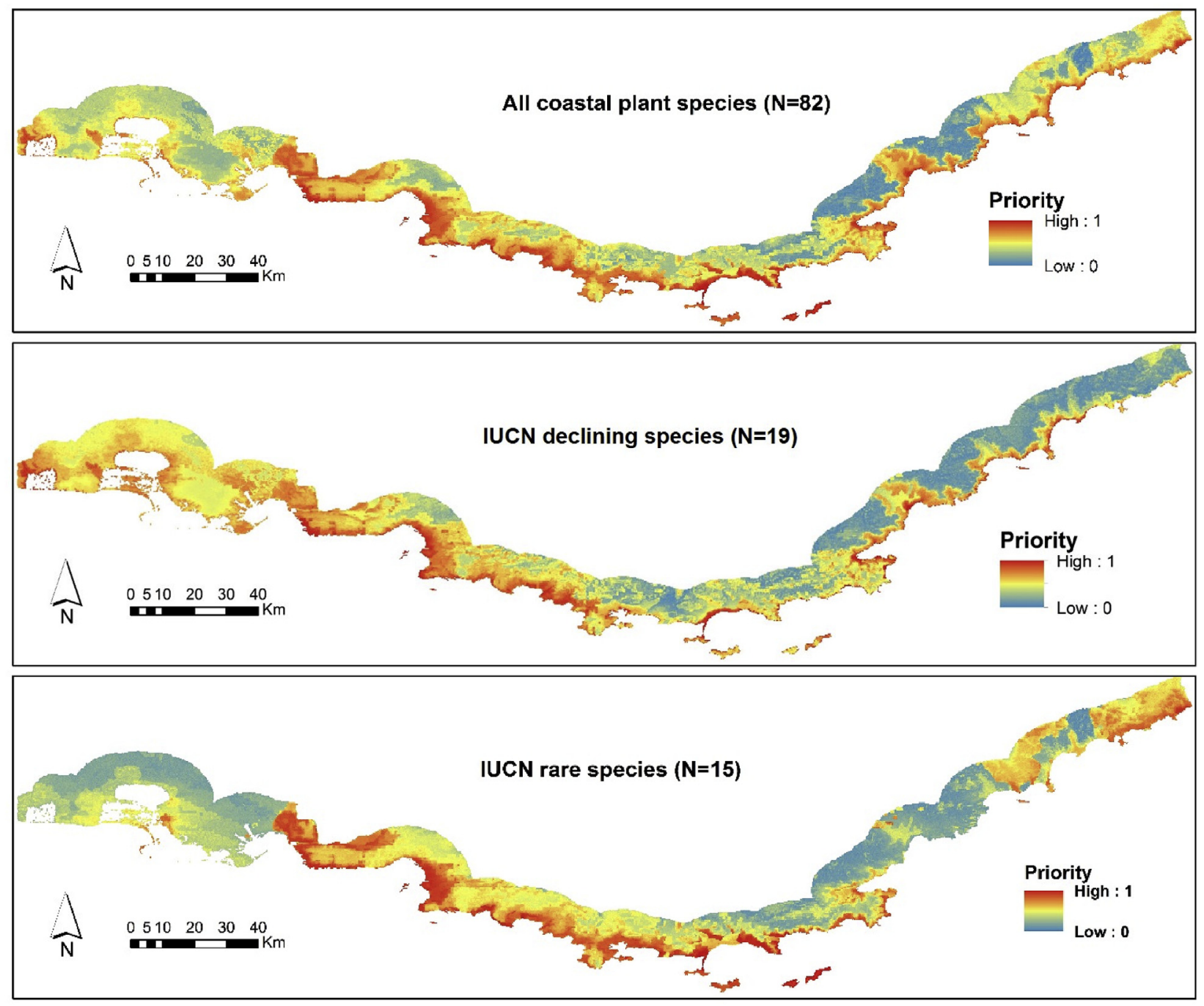

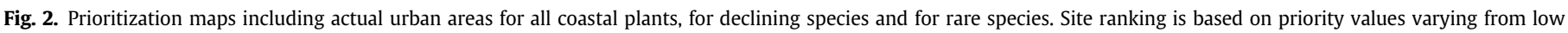
(blue) to high (red). (For interpretation of the references to colour in this figure legend, the reader is referred to the web version of this article.)

coastal plants (Fig. 5iii)

When considering the specific contribution of each protected area, we show that regarding strict PAs, important percentages of priority areas for coastal plants are located in National Parks (11\%) and in areas managed by the Coastal Conservation Agency (12\%, Appendix 3). Percentages were slightly higher for declining species, with priority sites being mostly located in areas managed by the Coastal Conservation Agency (19\%), the National Parks (10\%) and the National Nature Reserves (8\%). For rare species, the overlap was slightly lower, with $11 \%$ in National Parks and $10 \%$ in areas managed by the Coastal Conservation Agency.

For multi-use PAs, Natura 2000 sites cover a significant part of the priority areas for all three species groups i.e. $20 \%$ of priority areas for all considered plants, $15 \%$ for rare species and up to $29 \%$ for declining species. Regional Nature Parks are also important for declining species, covering $14 \%$ of their priority areas, but cover less than $1 \%$ of the priority areas for rare species and $4 \%$ of all species. The four remaining PA categories i.e. National and Regional Nature Reserves, Biological Reserves and Protection Biotopes, include minor percentages $(<5 \%)$ of priority areas for coastal plant species, which can be explained by the small surface they cover within the study region (Appendix 3).

\subsection{Selection of future strict PAs to anticipate future urbanization dynamics}

If future demographic trends and corresponding land-use changes follow the $1990-2012$ trend, an additional $1 \%-2 \%$ of the study region may become urban with respectively $25 \%$ and $26 \%$ urban cover, within the following 20 or 40 years. For these medium-term scenarios, the overlap with priority areas is low $(<6 \%$ ). For long-term scenarios with $30 \%$ of urban cover, over $17 \%$ of coastal plants priority areas may become urbanized (Fig. 6i). For all urbanization scenarios, the top $10 \%$ priority areas are stronger exposed to future urbanization: higher overlaps are expected for the top $10 \%$ than for the top $17 \%$ ranking. These results are consistent with those obtained on past urbanization, indicating that cities are over-represented in plant priority areas, thus their expansion will harm first the top priority areas.

This loss could be prevented if future strict PAs were extended to reach $17 \%$ of the study region by selecting areas with the highest conservation priority, based on all coastal species distributions. Under this scenario, the overlap between the top $10 \%$ priority sites and urban areas falls to $0 \%$ for all urbanization scenarios. Compared to the top $17 \%$ priorities, these additional strict PAs would result in a 


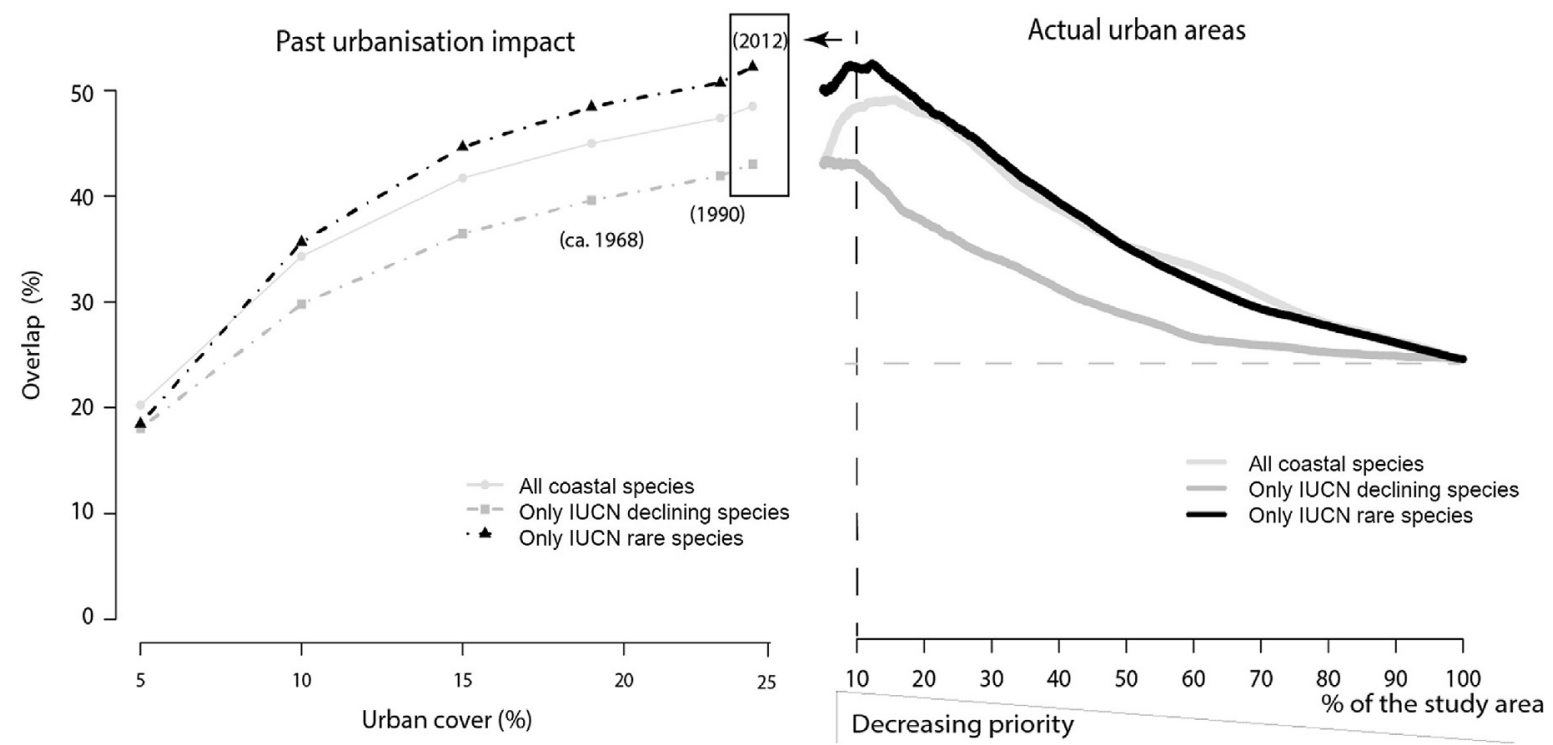

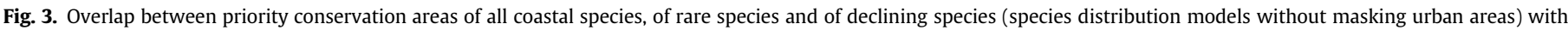

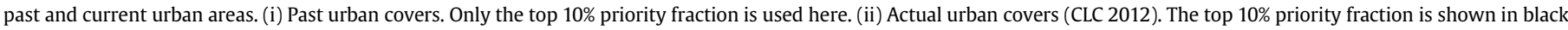
dashed line. The overlaps with multiple other fractions (top $20 \%, 30 \%$ etc) of the priority areas are also shown.

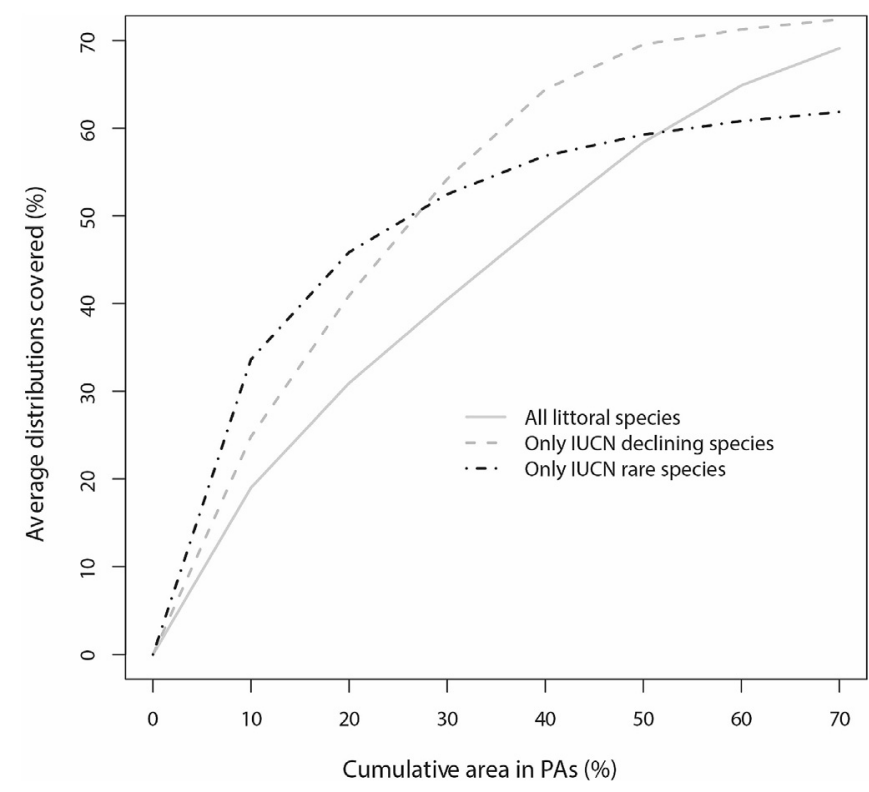

Fig. 4. Species average distributions under protection according to the surface considered in PAs. Sites are in decreasing priority order, a cumulative area of $10 \%$ corresponds to the top $10 \%$ priorities.

$2 \%$ future loss of top sites for rare species and even less for other species groups based on the two medium-term scenarios and for a maximum of $7 \%$ loss for rare species, $4 \%$ for declining species and $5 \%$ for all species based on the long-term scenario (Fig. 6ii and App. 4 for the complementary priority areas map).

If one considers only priority areas of rare species for additional strict PAs, this would limit losses of the $17 \%$ top priority areas to $5 \%$ for rare species (vs a $16 \%$ loss if no additional conservation effort is made) (App. 4). Similarly, when prioritizing only declining species, additional strict PAs would lead to a maximum loss in priority areas equal to $4 \%$ (App. 4). However, when focusing only on rare or declining species, the potential future losses for the other groups increase compared to those obtained by prioritizing all species, even for medium-term urbanization scenarios (Fig. 6ii vs App. 4): i.e. maximum of $6 \%$ loss for declining species and $7 \%$ loss for all species when prioritizing only rare species, and up to $11 \%$ for rare and all species when prioritizing only declining species.

\section{Discussion}

\subsection{Potential effect of past urbanization}

A large part of modelled plant distribution areas overlapped with actual coastal cities, indicating a strong past impact of cities on coastal plant diversity within our study region. Coastal urbanization has already removed half of the most important areas for the coastal plant species; this concerns particularly rare species and to a slightly lesser extent declining species. The urbanization impacts are still strong on species that strongly regressed during the last decades, such as Astragalus tragacantha, Viola arborescens or Euphorbia peplis, which are typically found in low elevation coastal land, where expanding urbanization may act first (Aboucaya, 2008; Vela et al., 2001). Our results suggest that some rare species regressed to current rarity in response to human pressures such as habitat destruction by urbanization (Collins et al., 2001; Luisa Martinez et al., 2014; Rebelo et al., 2011). This re-instates that plants of flat coastal areas suffer from multiple threats induced by urbanization (Lavergne et al., 2005; Lhotte et al., 2014) and calls for more attention to spatial overlap between habitat properties and threats, e.g. by preserving in priority flat low lying habitats (Lavergne et al., 2005; Aboucaya, 2008; Noble et al., 2015).

We also show that the strong overlap between priority areas for plant diversity and urban areas is not linked to urban expansion since 1990, but to impacts of urbanization half a century ago. This is consistent with history and early demographic expansion of the region's largest cities. Marseille and Nice were settled millennia ago but have undergone increased demographic expansion in the late 
(i)

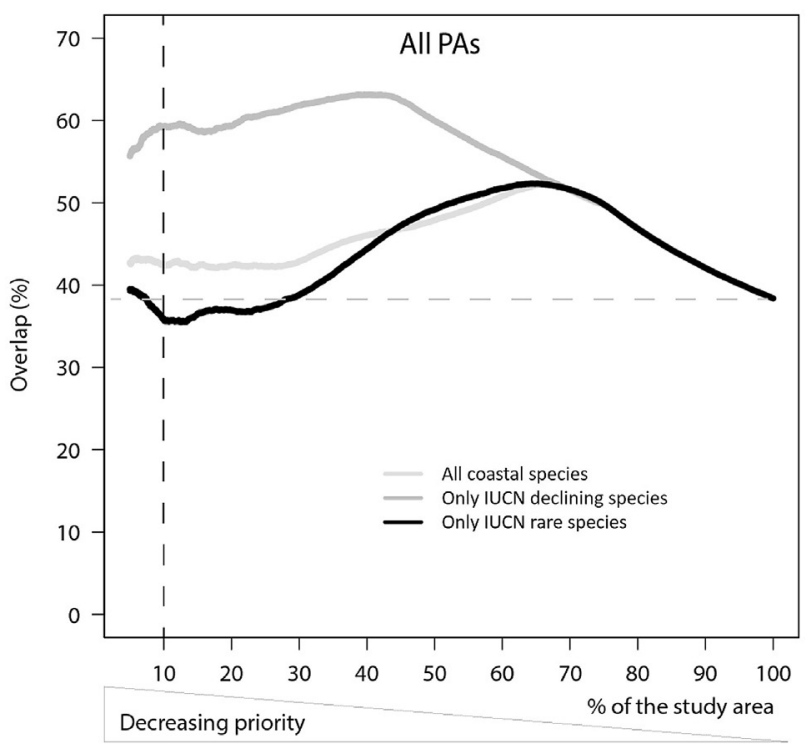

(ii)

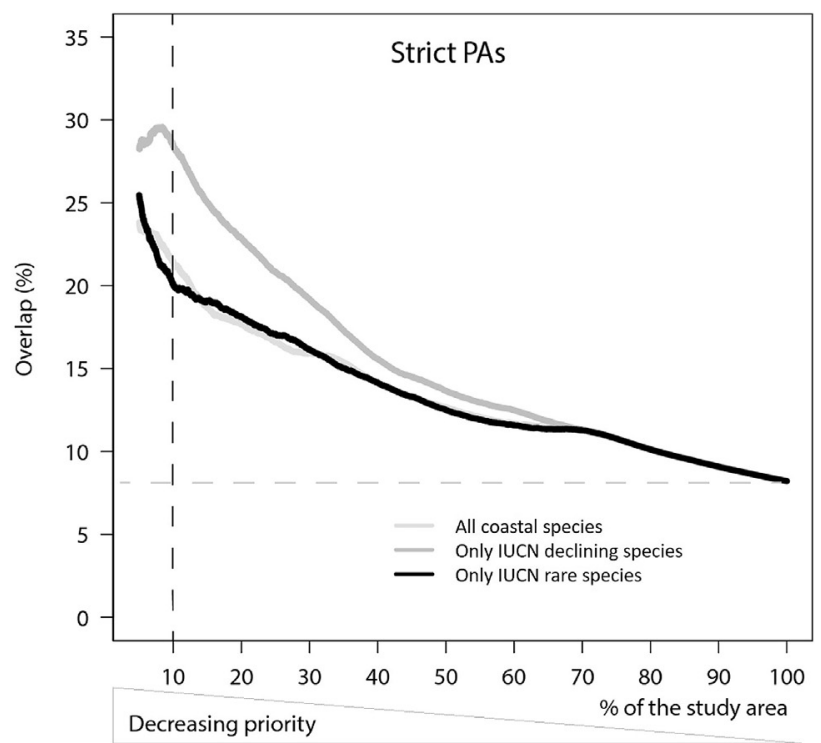

(iii)

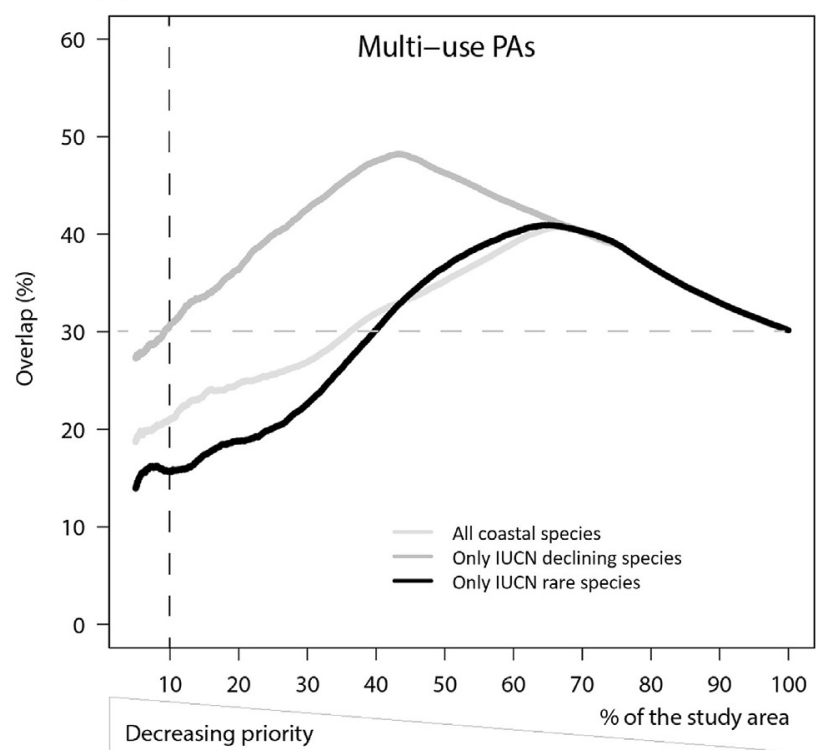

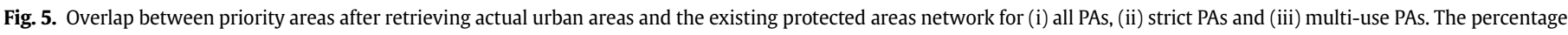

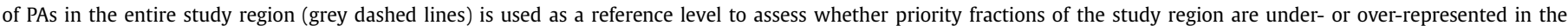
considered PAs. The top $10 \%$ priority fraction is shown in black dashed lines.

19th and 20th centuries, reaching a plateau after the 1990s (Bernard et al., 2011). Even though important, this loss represents relatively ancient habitat loss, highlighting the existence of human settlements in high diversity areas, which could be explained by favourable environmental conditions for both human and plant populations, as well as a putative dependency of human populations on rich plant communities (Pärtel et al., 2007). Yet, urbanization is still ongoing in the Mediterranean (Léon and Godefroy, 2006) while the connections between cities and natural areas are increasingly perceived as a factor of well-being (Carrus et al., 2015; Miller, 2005), increasing the necessity of preserving the remaining coastal natural habitats effectively.

\subsection{Identification of top conservation priorities and effectiveness of protected areas}

European and global conservation policies have led to a mosaic of different types of protected areas, including strictly protected and multi-use areas (McDonald and Boucher, 2011). In the PACA region, strict protected areas seem to be suitably located to protect coastal habitats from urbanization, but need to be further extended i.e. only one fifth to one third of the top $10 \%$ priority areas for both common and conservation interest species, are already included in strict PAs. Multi-use PAs, which predominate in the region, fail to adequately represent coastal plant priority areas, especially for plants of high conservation interest. Major exceptions are Natura 

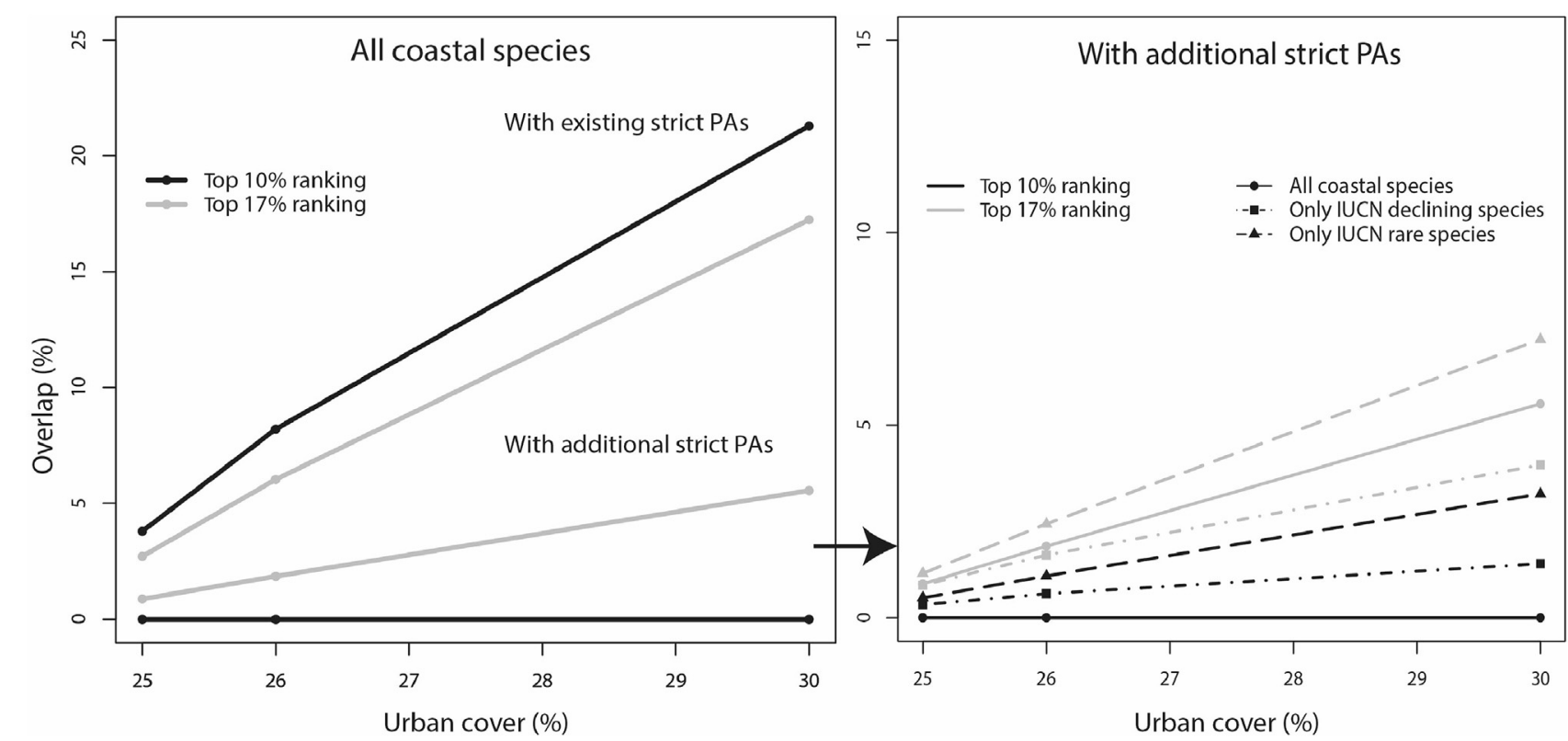

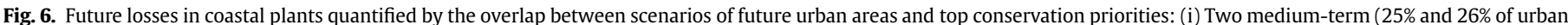

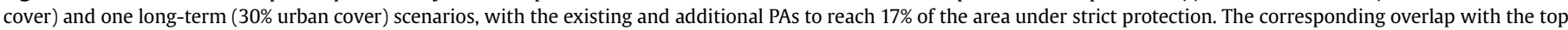

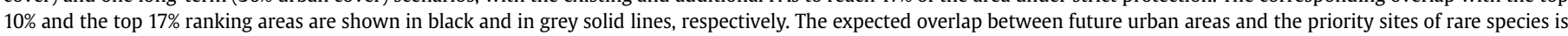

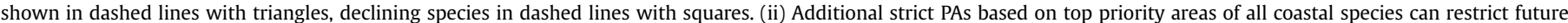
losses of top ranking areas to less than $7 \%$ for all plant groups.

2000 areas and the Camargue Regional Nature Park, which included high percentages of priority areas, especially for declining species.

Characterised by less strict management plans, the multi-use PAs can be exposed to further degradation, caused by future urbanization or other human pressures. To date, Natura 2000 has low management intensity, restrictions are few and highly flexible and even total destruction can be acceptable, when overriding public interests are claimed (EEC Council Directive, 1992). Given its use as a major conservation tool in Europe, Natura 2000 should be reinforced to achieve future conservation targets (Pullin et al., 2009). Other sites, such as the Camargue Regional Nature Park, become increasingly important for coastal conservation. Since Camargue is known as an outstanding wetland site in France, management may be more easily applied and sustained by more traditional human activities, with a milder impact on plant diversity. Moreover, given the high water table and unstable alluvial deposits, urbanization seems to be an unlikely future risk for this area.

\subsection{Extending the PA network to counter the potential effect of future urbanization}

The population density close to Mediterranean coasts is already proportionately high - one third of the population currently lives in coastal regions - and is expected to increase, leading to more intensive urban development in coastal regions than anywhere else (UNEP/MAP, 2012). France figures among the most highly populated Mediterranean countries together with Spain, Italy, Egypt and Turkey (UNDESA, 2015). It is thus more than reasonable to expect further urbanization on the Mediterranean coasts and future conservation objectives should therefore aim at stopping any further loss in priority areas (Harrop, 2011).

Given the limited effectiveness in protecting coastal ecosystems against urbanization, it is necessary to reinforce the existing network of protected areas by converting top priority sites into strict protected areas. If no additional urban construction restrictions are imposed via the designation of additional strict PAs, up to one tenth of the top $10 \%$ priority areas of both common and conservation interest species could be lost, under medium-term scenarios. Future losses may even reach one fifth of the priority areas, with the highest impact on rare species, under the long-term scenario. Given that the impact of past urbanization has already diminished coastal plant priority areas to half of its potential, even moderate future loss may considerably increase the future vulnerability of coastal vegetation, as rare and declining species' irreplaceable sites may become urbanized.

Following the Aichi biodiversity objectives for 2020 (https:// www.cbd.int/sp), we suggest future strict PA networks to reach $17 \%$ of the total area under protection, thus shifting the expansion of urban areas beyond these new protected areas. Interestingly, we show that prioritizing most irreplaceable sites for all species, we manage to effectively protect common, rare and declining species even for long-term urbanization scenarios. Earlier conservation practices tended to prioritise conservation interest species without considering the most common species (Mittermeier et al., 2004). However, recent practice is to seek a compromise between the conservation of both common and rare species (Gaston and Fuller, 2008; Jiguet and Julliard, 2006). This more holistic approach is of interest for coastal ecosystems, as the species' restricted niche and the high level of human pressure may easily expose species, even those that are not currently threatened, to future risks. Species that do not currently fulfil the IUCN conditions may become more vulnerable in the future, thus selecting future protected areas among the priority areas of all analysed species seems the best strategy to minimize future risks.

\subsection{Conclusions}

Certainly, the application of conservation prioritization coastal plans is a complex task (Beger et al., 2010; Poe et al., 2014; Rudd and Lawton, 2013). In this study, we deliberately chose to focus on urbanization, as the main threat to coastal ecosystems worldwide (Lai 
et al., 2015; McDonald and Boucher, 2011). Climate change impacts, inducing sea level rise, also have effects on coastal biodiversity and induce a coastal squeeze (Luisa Martinez et al., 2014). However, sea level changes are expected to have minor effects in the study region in the near future (Vacchi et al., 2016). Our prioritization approach may be completed by further criteria. For instance, we simply considered all non-urban areas as equally suitable for biodiversity conservation and future studies might include differences in social or economic costs for setting aside these areas. Of course, prioritization decisions should be taken in order to reconcile both social and conservation values (Stigner et al., 2016) and detailed socioeconomic data as well as biodiversity and habitat connectivity data should also be taken into account in conservation planning (Arponen et al., 2010; Di Minin et al., 2013; Moilanen et al., 2011a, 2011b). In addition, optimal conservation of coastal and other ecosystems requires to go beyond national boundaries and to set conservation targets at large scale (Moilanen and Arponen, 2011).

Our case study underlines the usefulness of urbanization and conservation planning scenarios and illustrated how to quantify past and future losses of conservation priorities. It also highlights different roles of strict versus multi-use PAs, a capital issue to global conservation effectiveness worldwide. Only a small part of the remaining coastal priority areas is under strict protection, hence management that focusses on common and conservation target species should be considered to meet conservation goals. Analyses coupling spatial conservation prioritization and simulations of land use change are still scarce but may help managers and decisionmakers to better identify priorities and conservation strategies.

\section{Acknowledgements}

We warmly thank the numerous botanists that contributed data to the SILENE database and the Mediterranean Botanical Conservatory, Virgile Noble for providing data and région PACA maintenance of the database. We thank the National Park of Calanques and Port Cros, Lidwine Le Mire Pecheux, Elodie Debize and Annie Aboucaya, for discussions and for contributing to the protected area network selection. This work is part of the GREAT Med project and is financed by the European Union (ENPI CBC Mediterranean Sea Basin Programme) through the European Neighborhood and Partnership Instrument (Grant Agreement no. 39/2377). This work contributes to the Labex OT-Med (no ANR-11-LABX-0061) funded by the French government through the A*MIDEX project (no ANR11-IDEX-0001-02).

\section{References}

Aboucaya, A., 2008. In: Naturalia (Ed.), Le Var et sa flore: plantes rares ou protégées Naturalia Publications. Var.

Airoldi, L., Beck, M.W., 2007. Loss, status and trends for coastal marine habitats of Europe. Oceanogr. Mar. Biol. 45, 345-405. http://dx.doi.org/10.1201/ 9781420050943.

Araujo, M.B., Thuiller, W., Williams, P.H., Reginster, I., 2005. Downscaling European species atlas distributions to a finer resolution: implications for conservation planning. Glob. Ecol. Biogeogr. 14, 17-30. http://dx.doi.org/10.1111/j.1466822X.2004.00128.x.

Arponen, A., Cabeza, M., Eklund, J., Kujala, H., Lehtomäki, J., 2010. Costs of integrating economics and conservation planning. Conserv. Biol. 24, 1198-1204. http://dx.doi.org/10.1111/j.1523-1739.2010.01539.x.

Aspinall, R., 2004. Modelling land use change with generalized linear models - a multi-model analysis of change between 1860 and 2000 in Gallatin Valley, Montana. J. Environ. Manage. 72, 91-103. http://dx.doi.org/10.1016/ j.jenvman.2004.02.009.

Baastrup-Spohr, L., Iversen, L.L., Borum, J., Sand-Jensen, K., 2015. Niche specialization and functional traits regulate the rarity of charophytes in the Nordic countries. Aquat. Conserv. Mar. Freshw. Ecosyst. 25, 469-481. http:// dx.doi.org/10.1002/aqc.2544.

Bacchetta, G., Farris, E., Pontecorvo, C., 2011. A new method to set conservation priorities in biodiversity hotspots. Plant Biosys. - Int. J. Deal. all Asp. Plant Biol. 146, 1-11. http://dx.doi.org/10.1080/11263504.2011.642417.

Barbet-Massin, M., Jiguet, F., Albert, C.H., Thuiller, W., 2012. Selecting pseudoabsences for species distribution models: how, where and how many? Methods Ecol. Evol. 3, 327-338. http://dx.doi.org/10.1111/j.2041210X.2011.00172.X.

Beger, M., Grantham, H.S., Pressey, R.L., Wilson, K.A., Peterson, E.L., Dorfman, D., Mumby, P.J., Lourival, R., Brumbaugh, D.R., Possingham, H.P., 2010. Conservation planning for connectivity across marine, freshwater, and terrestrial realms. Biol. Conserv. http://dx.doi.org/10.1016/j.biocon.2009.11.006.

Bernard, J., Chéron, S., Pougnard, J., 2011. Marseille Provence Métropole Précarité, vieillissement, déplacements... de nombreux défis à relever. INSEE Etudes Provence-Alpes-Côte d'Azur.

Brooks, T.M., Mittermeier, R.A., da Fonseca, G.A.B., Gerlach, J., Hoffmann, M., Lamoreux, J.F., Mittermeier, C.G., Pilgrim, J.D., Rodrigues, A.S.L., 2006. Global biodiversity conservation priorities. Science 313, 58-61. http://dx.doi.org/ 10.1126/science.1127609.

Brown, A.C., McLachlan, A., 2006. The ecology of sandy shores. In: The Ecology of Sandy Shores, second ed. Academic Press, Burlington. http://dx.doi.org/10.1016/ B978-012372569-1/50015-X.

Bulleri, F., Chapman, M.G., 2010. The introduction of coastal infrastructure as a driver of change in marine environments. J. Appl. Ecol. http://dx.doi.org/ 10.1111/j.1365-2664.2009.01751.x.

Bürgi, M., Hersperger, a. M., Schneeberger, N., 2004. Driving forces of landscape change-current and new directions. Landsc. Ecol. 19, 857-868. http:// dx.doi.org/10.1007/s10980-004-0245-8.

Cabeza, M., Moilanen, A., 2001. Design of reserve networks and the persistence of biodiversity. Trends Ecol. Evol. http://dx.doi.org/10.1016/S0169-5347(01)021255 .

Carrus, G., Scopelliti, M., Lafortezza, R., Colangelo, G., Ferrini, F., Salbitano, F., Agrimi, M., Portoghesi, L., Semenzato, P., Sanesi, G., 2015. Go greener, feel better? The positive effects of biodiversity on the well-being of individuals visiting urban and peri-urban green areas. Landsc. Urban Plan. 134, 221-228. http:|| dx.doi.org/10.1016/j.landurbplan.2014.10.022.

Collins, B., White, P., Imm, D., 2001. Introduction to ecology and management of rare plants of the southeast. Nat. Areas J. 21, 4-11.

Cox, R.L., Underwood, E.C., 2011. The importance of conserving biodiversity outside of protected areas in mediterranean ecosystems. PLoS One 6, e14508. http:// dx.doi.org/10.1371/journal.pone.0014508.

Di Minin, E., Macmillan, D.C., Goodman, P.S., Escott, B., Slotow, R., Moilanen, A., 2013. Conservation businesses and conservation planning in a biological diversity hotspot. Conserv. Biol. 27, 808-820. http://dx.doi.org/10.1111/ cobi.12048.

Doxa, A., Holon, F., Deter, J., Villéger, S., Boissery, P., Mouquet, N., 2016. Mapping biodiversity in three-dimensions challenges marine conservation strategies: the example of coralligenous assemblages in North-Western Mediterranean Sea. Ecol. Indic. 61, 1042-1054. http://dx.doi.org/10.1016/j.ecolind.2015.10.062.

EEC Council Directive, 1992. On the conservation of natural habitats and of wild fauna and flora. Off. J. Eur. Communities L 269, 1-15.

Elith, J., Graham, H., C., P, Anderson, R., Dudík, M., Ferrier, S., Guisan, A., J. Hijmans, R., Huettmann, F., R. Leathwick, J., Lehmann, A., Li, J., G. Lohmann, L., A Loiselle, B., Manion, G., Moritz, C., Nakamura, M., Nakazawa, Y., McC. M. Overton, J., Townsend Peterson, A., J. Phillips, S., Richardson, K., ScachettiPereira, R., E. Schapire, R., Soberón, J., Williams, S., S. Wisz, M., E. Zimmermann, N., 2006. Novel methods improve prediction of species' distributions from occurrence data. Ecogr. (Cop.) 29, 129-151. http://dx.doi.org/ 10.1111/j.2006.0906-7590.04596.x.

Fenu, G., Carboni, M., Acosta, A.T.R., Bacchetta, G., 2013. Environmental factors influencing coastal vegetation pattern: new insights from the Mediterranean basin. Folia Geobot. 48, 493-508. http://dx.doi.org/10.1007/s12224-012-9141-1.

Forey, E., Chapelet, B., Vitasse, Y., Tilquin, M., Touzard, B., Michalet, R., 2008. The relative importance of disturbance and environmental stress at local and regional scales in French coastal sand dunes. J. Veg. Sci. 19, 493-502. http:// dx.doi.org/10.3170/2008-8-18392.

Gaston, K.J., Fuller, R.A., 2008. Commonness, population depletion and conservation biology. Trends Ecol. Evol. 23, 14-19. http://dx.doi.org/10.1016/ j.tree.2007.11.001.

Gauthier, P., Debussche, M., Thompson, J.D., 2010. Regional priority setting for rare species based on a method combining three criteria. Biol. Conserv. 143, 1501-1509. http://dx.doi.org/10.1016/j.biocon.2010.03.032.

Gauthier, P., Foulon, Y., Jupille, O., Thompson, J.D., 2013. Quantifying habitat vulnerability to assess species priorities for conservation management. Biol. Conserv. 158, 321-325. http://dx.doi.org/10.1016/j.biocon.2012.08.012.

Greuter, W., 1994. Extinctions in mediterranean areas. Philos. Trans. R. Soc. B Biol. Sci. 344, 41-46. http://dx.doi.org/10.1098/rstb.1994.0049.

Grimm, N.B., Faeth, S.H., Golubiewski, N.E., Redman, C.L., Wu, J., Bai, X., Briggs, J.M., 2008. Global change and the ecology of cities. Science 319, 756-760. http:// dx.doi.org/10.1126/science.1150195.

Harrop, S.R., 2011. "Living in Harmony with nature"? Outcomes of the 2010 Nagoya conference of the convention on biological diversity. J. Environ. Law 23, 117-128. http://dx.doi.org/10.1093/jel/eqq032. 
Hijmans, R.J., Cameron, S.E., Parra, J.L., Jones, P.G., Jarvis, A., 2005. Very high resolution interpolated climate surfaces for global land areas. Int. J. Climatol. 25, 1965-1978. http://dx.doi.org/10.1002/joc.1276.

Hu, Z., Lo, C.P., 2007. Modeling urban growth in Atlanta using logistic regression. Comput. Environ. Urban Syst. 31, 667-688. http://dx.doi.org/10.1016/ j.compenvurbsys.2006.11.001.

Jenkins, C.N., Joppa, L., 2009. Expansion of the global terrestrial protected area system. Biol. Conserv. 142, 2166-2174. http://dx.doi.org/10.1016/ j.biocon.2009.04.016.

Jiguet, F., Julliard, R., 2006. Inferences from common species communities for selecting conservation areas. Biodivers. Conserv. 15, 799-815. http://dx.doi.org/ 10.1007/s10531-004-1067-3.

Lai, S., Loke, L.H.L., Hilton, M.J., Bouma, T.J., Todd, P.A., 2015. The effects of urbanisation on coastal habitats and the potential for ecological engineering: a Singapore case study. Ocean. Coast. Manag. 103, 78-85. http://dx.doi.org/ 10.1016/j.ocecoaman.2014.11.006.

Lavergne, S., Thompson, J.D., Garnier, E., Debussche, M., 2004. The biology and ecology of narrow endemic and widespread plants: a comparative study of trait variation in 20 congeneric pairs. Oikos 107, 505-518. http://dx.doi.org/10.1111/ j.0030-1299.2004.13423.x.

Lavergne, S., Thuiller, W., Molina, J., Debussche, M., 2005. Environmental and human factors influencing rare plant local occurrence, extinction and persistence: a 115-year study in the Mediterranean region. J. Biogeogr. 32, 799-811. http:// dx.doi.org/10.1111/j.1365-2699.2005.01207.x.

Lehtomäki, J., Moilanen, A., 2013. Methods and workflow for spatial conservation prioritization using Zonation. Environ. Model. Softw. 47, 128-137. http:/ dx.doi.org/10.1016/j.envsoft.2013.05.001.

Léon, O., Godefroy, P., 2006. Projections régionales de population à l'horizon 2030 Fortes croissances au Sud et à l'Ouest. INSEE Paris.

Leroux, S.J., Krawchuk, M.A., Schmiegelow, F., Cumming, S.G., Lisgo, K., Anderson, L.G., Petkova, M., 2010. Global protected areas and IUCN designations: do the categories match the conditions? Biol. Conserv. 143, 609-616. http://dx.doi.org/10.1016/j.biocon.2009.11.018.

Lhotte, A., Affre, L., Saatkamp, A., 2014. Are there contrasted impacts of urbanization and land uses on population persistence? The case of Teucrium pseudochamaepitys, an endangered species in Southern France. Flora Morphol. Distrib. Funct. Ecol. Plants 209, 484-490. http://dx.doi.org/10.1016/j.flora.2014.05.002.

Li, J., Yang, X., 2015. Monitoring and Modelling of Global Changes: a Geomatics Perspective. Springer, Dordrecht.

Luisa Martinez, M., Mendoza-Gonzalez, G., Silva-Casarin, R., Mendoza-Baldwin, E., 2014. Land use changes and sea level rise may induce a "coastal squeeze" on the coasts of Veracruz, Mexico. Glob. Environ. Chang. 29, 180-188. http:// dx.doi.org/10.1016/j.gloenvcha.2014.09.009.

Malcolm, J.R., Zedler, P.H., 1995. Plant life history and dynamic specialization in the chaparral/coastal sage shrub flora in southern California. In: Ecology and Biogeography of Mediterranean Ecosystems in Chile, California and Australia, pp. $2115-2438$

Margules, C.R., Pressey, R.L., 2000. Systematic conservation planning. Nature 405, 243-253. http://dx.doi.org/10.1038/35012251.

McDonald, R.I., Boucher, T.M., 2011. Global development and the future of the protected area strategy. Biol. Conserv. 144, 383-392. http://dx.doi.org/10.1016/ j.biocon.2010.09.016.

McKinney, M.L., 2002. Urbanization, biodiversity, and conservation. Bioscience. http://dx.doi.org/10.1641/0006-3568(2002)052[0883:UBAC]2.0.CO;2.

Médail, F., Quézel, P., 1997. Hotspots analysis for conservation of plant biodiversity in the Mediterranean basin. Ann. Mo. Bot. Gard. 84, 112-127. http://dx.doi.org/ $10.2307 / 2399957$.

Médail, F., Verlaque, R., 1997. Ecological characteristics and rarity of endemic plants from Southeast France and Corsica: implications for biodiversity conservation. Biol. Conserv. 80, 269-281. http://dx.doi.org/10.1016/S0006-3207(96)00055-9.

Meller, L., Cabeza, M., Pironon, S., Barbet-Massin, M., Maiorano, L., Georges, D., Thuiller, W., 2014. Ensemble distribution models in conservation prioritization: from consensus predictions to consensus reserve networks. Divers. Distrib. 20, 309-321. http://dx.doi.org/10.1111/ddi.12162.

Miller, J.R., 2005. Biodiversity conservation and the extinction of experience. Trends Ecol. Evol. http://dx.doi.org/10.1016/j.tree.2005.05.013.

Mittermeier, R.A.A., Gil, P.R., Hoffman, M., Pilgrim, J., Brooks, T., Mittermeier, C.G.G., Lamoreux, J., Da Fonseca, G.A.B.A.B., Robles Gil, P., 2004. Hotspots Revisited: Earth's Biologically Richest and Most Endangered Ecoregions, Sierra. Graphic Arts Center Publishing Company, Portland. http://dx.doi.org/10.1046/j.15231739.2002.00530.x.

Moilanen, A., Arponen, A., 2011. Administrative regions in conservation: balancing local priorities with regional to global preferences in spatial planning. Biol. Conserv. 144, 1719-1725. http://dx.doi.org/10.1016/j.biocon.2011.03.007.

Moilanen, A., Wilson, K.A., Possingham, H.P., 2009. Spatial Conservation Prioritization: Quantitative Methods and Computational Tools. Oxford University Press, Oxford.

Moilanen, A., Anderson, B.J., Eigenbrod, F., Heinemeyer, A., Roy, D.B., Gillings, S., Armsworth, P.R., Gaston, K.J., Thomas, C.D., 2011a. Balancing alternative land uses in conservation prioritization. Ecol. Appl. 21, 1419-1426. http://dx.doi.org/ 10.1890/10-1865.1.

Moilanen, A., Leathwick, J.R., Quinn, J.M., 2011b. Spatial prioritization of conservation management. Conserv. Lett. 4, 383-393. http://dx.doi.org/10.1111/j.1755263X.2011.00190.x.
Moilanen, A., Pouzols, F.M., Meller, L., Veach, V., Arponen, A., Leppänen, J., Kujala, H. 2014. Spatial Conservation Planning Methods and Software Zonation. User Manual. Version 4. Helsinki.

Montesino Pouzols, F., Toivonen, T., Di Minin, E., Kukkala, A.S., Kullberg, P., Kuusterä, J., Lehtomäki, J., Tenkanen, H., Verburg, P.H., Moilanen, A., 2014. Global protected area expansion is compromised by projected land-use and parochialism. Nature 516, 383-386. http://dx.doi.org/10.1038/nature14032.

Mouillot, D., Albouy, C., Guilhaumon, F., Ben Rais Lasram, F., Coll, M., Devictor, V. Meynard, C.N., Pauly, D., Tomasini, J.A., Troussellier, M., Velez, L., Watson, R. Douzery, E.J.P., Mouquet, N., 2011. Protected and threatened components of fish biodiversity in the Mediterranean sea. Curr. Biol. 21, 1044-1050. http:// dx.doi.org/10.1016/j.cub.2011.05.005.

Noble, V. Van Es, J. Michaud, H., Garraud, L, 2015. Catalogue de la flore vasculaire de la région Provence-Alpes-Côte d'Azur. Conservatoires botaniques nationaux alpin et méditerranéen, Hyères.

Pärtel, M., Helm, A., Reitalu, T., Liira, J., Zobel, M., 2007. Grassland diversity related to the Late Iron Age human population density. J. Ecol. 95, 574-582. http:// dx.doi.org/10.1111/j.1365-2745.2007.01230.x.

Poe, M.R., Norman, K.C., Levin, P.S., 2014. Cultural dimensions of socioecological systems: key connections and guiding principles for conservation in coastal environments. Conserv. Lett. 7, 166-175. http://dx.doi.org/10.1111/conl.12068.

Pouget, M., Youssef, S., Dumas, P.J., Baumberger, T., San Roman, A., Torre, F., Affre, L., Médail, F., Baumel, A., 2016. Spatial mismatches between plant biodiversity facets and evolutionary legacy in the vicinity of a major Mediterranean city Ecol. Indic. 60, 736-745. http://dx.doi.org/10.1016/j.ecolind.2015.07.017.

Pressey, R.L., Watts, M.E., Barrett, T.W., 2004. Is maximizing protection the same as minimizing loss? Efficiency and retention as alternative measures of the effectiveness of proposed reserves. Ecol. Lett. 7, 1035-1046. http://dx.doi.org/ 10.1111/j.1461-0248.2004.00672.x.

Pressey, R.L., Cabeza, M., Watts, M.E., Cowling, R.M., Wilson, K.A., 2007. Conservation planning in a changing world. Trends Ecol. Evol. 22, 583-592. http:// dx.doi.org/10.1016/j.tree.2007.10.001.

Pullin, A.S., BÁldi, A., Can, O.E., Dieterich, M., Kati, V., Livoreil, B., LÖvei, G., Mihók, B. Nevin, O., Selva, N., Sousa-Pinto, I., 2009. Conservation focus on europe: major conservation policy issues that need to be informed by conservation science. Conserv. Biol. 23, 818-824. http://dx.doi.org/10.1111/j.1523-1739.2009.01283.x.

Rebelo, A.G., Holmes, P.M., Dorse, C., Wood, J., 2011. Impacts of urbanization in a biodiversity hotspot: conservation challenges in metropolitan cape town. South Afr. J. Bot. 77, 20-35. http://dx.doi.org/10.1016/j.sajb.2010.04.006.

Rudd, M.A., Lawton, R.N., 2013. Scientists' prioritization of global coastal research questions. Mar. Policy 39, 101-111. http://dx.doi.org/10.1016 j.marpol.2012.09.004.

Ruocco, M., Bertoni, D., Sarti, G., Ciccarelli, D., 2014. Mediterranean coastal dune systems: which abiotic factors have the most influence on plant communities? Estuar. Coast. Shelf Sci. 149, 213-222. http://dx.doi.org/10.1016/ j.ecss.2014.08.019.

Schatz, B., Gauthier, P., Debussche, M., Thompson, J.D., 2014. A decision tool for listing species for protection on different geographic scales and administrative levels. J. Nat. Conserv. 22, 75-83. http://dx.doi.org/10.1016/j.jnc.2013.09.003.

Seavey, J.R., Gilmer, B., McGarigal, K.M., 2011. Effect of sea-level rise on piping plover (Charadrius melodus) breeding habitat. Biol. Conserv. 144, 393-401. http:// dx.doi.org/10.1016/j.biocon.2010.09.017.

Seto, K.C., Fragkias, M., Güneralp, B., Reilly, M.K., 2011. A meta-analysis of global urban land expansion. PLoS One 6, 1-9. http://dx.doi.org/10.1371 journal.pone.0023777.

Stefanaki, A., Kantsa, A., Tscheulin, T., Charitonidou, M., Petanidou, T., 2015. Lessons from red data books: plant vulnerability increases with floral complexity. PLoS One 10, e0138414. http://dx.doi.org/10.1371/journal.pone.0138414.

Stigner, M.G., Beyer, H.L., Klein, C.J., Fuller, R.A., Carvalho, S., 2016. Reconciling recreational use and conservation values in a coastal protected area. J. Appl. Ecol. 53, 1206-1214. http://dx.doi.org/10.1111/1365-2664.12662.

Thuiller, W., Araújo, M.B., Lavorel, S., 2003. Generalized models vs. classification tree analysis: predicting spatial distributions of plant species at different scales. J. Veg. Sci. 14, 669-680. http://dx.doi.org/10.1111/j.1654-1103.2003.tb02199.x.

Thuiller, W., Lafourcade, B., Engler, R., Araújo, M.B., 2009. BIOMOD - a platform for ensemble forecasting of species distributions. Ecogr. (Cop.) 32, 369-373. http:// dx.doi.org/10.1111/j.1600-0587.2008.05742.x.

United Nations, Department of Economic and Social Affairs, Population Division, 2015. World Population Prospects: The 2015 Revision, Key Findings and Advance Tables. Working Paper No. ESA/P/WP.241.

UNEP/MAP, 2012. State and Pressure of the Marine and Coastal Mediterranean Environment. UNEP/MAP - Barcelona Convention, Athens.

Department of economic and social affairs of the united nations population division (UNPD), 2012. World Urbanization Prospects: the 2011 Revision. http:// dx.doi.org/10.2307/2808041. United Nations. United Nations, New York.

Vacchi, M., Marriner, N., Morhange, C., Spada, G., Fontana, A., Rovere, A., 2016. Multiproxy assessment of Holocene relative sea-level changes in the western Mediterranean: variability in the sea-level histories and redefinition of the isostatic signal. Earth Sci. Rev. 155, 172-197. http://dx.doi.org/10.1016/ j.earscirev.2016.02.002.

Vela, E., Pavon, D., Giraud, R., Stefano, M. Di, Saatkamp, A., 2001. Liste des plantes vasculaires du site classé des Calanques. Bull. la Société Linnéenne Provence 52, $139-148$. 